\title{
Alasan Pelanggaran Prinsip Kerja Sama Grice dalam Program Mata Najwa di Trans 7
}

\section{Yulia Citra ${ }^{1}$}

\section{Fatmawati $^{2}$}

\section{Universitas Islam Riau Pekanbaru}

1yuliacitra99@student.uir.ac.id

2fatmawati@edu.uir.ac.id

\section{Abstrak}

Adanya perbedaan penerapan prinsip kerja sama yang dikemukan oleh Grice dengan yang terjadi di Indonesia menyebabkan pelanggaran prinsip kerja sama sering terjadi. Hal ini membuat penulis tertarik untuk melakukan penelitian tentang pelanggaran prinsip kerja sama Grice dalam program Mata Najwa di Tran 7. Sumber data dalam penelitian ini adalah aktivitas berbahasa yang terjadi dalam program Mata Najwa dengan tema Bara di Markas Jaksa pada hari Rabu 28 Agustus 2020. Penelitian ini menggunakan metode analisis isi. Pengumpulan data menggunakan teknik dokumentasi, simak, dan catat. Hasil penelitian ini adalah dari 271 tuturan ditemukan 83 tuturan yang dilanggar. Dari 83 data tuturan tersebut terdapat 25 tuturan yang melanggar maksim kuantitas dengan 6 kategori alasan pelanggarannya. Untuk maksim kualitas terdapat 8 tuturan yang melanggar dengan 5 kategori alasan pelanggarannya. Selanjutnya, untuk maksim relevansi terdapat 23 tuturan yang melanggar dengan 7 kategori alasan pelanggarannya. Untuk maksim cara/pelaksanaan terdapat 27 tuturan yang melanggar maksim cara/pelaksaan dengan 7 kategori alasan pelanggarannya. Adapun jenis pelanggaran keempat maksim tersebut adalah berbagi informasi, keramahan, kesantunan, humor, menyangkal, menegaskan, kesal, mengelak, penolakan, memerintah, provokasi, sindiran, keakraban, pembelaan diri, basa-basi, dan tidak tahu jawaban pasti. Meskipun terjadi pelanggaran, lawan tutur tidak mempermasalahkannya dan percakapan tetap berjalan dengan baik. Pelanggaran pada maksim-maksim Grice adalah suatu peristiwa yang biasa terjadi. Perbedaan budaya membuat prinsip kerja sama Grice tidak berlaku universal untuk semua bahasa. Khususnya yang terjadi dalam program Mata Najwa Bara di Markas Jaksa di Trans 7.

Kata kunci: Pelanggaran, Maksim kuantitas, Maksim Kualitas, Maksim relevnsi, Maksim cara/pelaksanaan

\section{Pendahuluan}

Prinsip kerja sama merupakan bagian dari pragmatis. Prinsip ini menekankan bahwa ada bentuk kerja sama antara penutur dan mitra tutur dalam suatu dialog. Kerja sama yang bermasalah terkait dengan kata-kata yang diucapkan. Oleh karena itu, penutur selalu berusaha agar ucapannya relevan dengan konteks, jelas, mudah dipahami, dan ringkas. Hal ini dirangkum dalam maksim-maksim yang terdapat dalam prinsip kerja sama. 
Bentuk kerja sama yang dimaksud adalah prinsip kerja sama yang digagas oleh Grice. Prinsip kerja sama Grice ini bertujuan untuk menguraikan tentang tindakan penutur dan mitra tutur dalam suatu percakapan. Grice dalam Wijana (1996:46) mengatakan bahwa dalam melakukan prinsip kerja sama setiap penutur haruslah menerapkan 4 (empat) maksim percakapan di antaranya, yaitu: (1) maksim kuantitas, (2) maksim kualitas, (3) maksim relevansi, dan (4) maksim pelaksanaan/cara. Maksim adalah prinsip yang wajib dipatuhi oleh penutur dalam berkorelasi, baik secara harfiah ataupun hubungan antar pribadi, supaya komunikasi berjalan dengan lancar.

Secara ringkas maksim-maksim prinsip kerja sama Grice akan dielaborasi di bawah ini. Pertama adalah maksim kuantitas. Maksim kuantitas menginginkan supaya partisipan menyumbangkan informasi secukupnya serta tidak lewat batas dalam menyampaikan penjelasan yang diperlukan oleh lawan tutur. Kedua adalah maksim kualitas. Dalam maksim kualitas menginginkan supaya partisipan menyampaikan informasi sesuai dengan faktanya disertai dengan bukti-bukti yang ada. Ketiga adalah maksim relevansi. Maksim relevansi menginginkan supaya partisipan menyampaikan sumbangan yang sesuai atas topik pembahasan. Keempat adalah maksim cara/pelaksanaan. Maksim cara menghendaki tiap partisipan tutur untuk bertutur ala singkat, mudah dipahami, dan tidak ambigu ataupun membingungkan sehingga tidak menimbulkan pertanyaan baru.

Penerapan prinsip kerja sama merupakan lawan dari pelanggaran prinsip kerja sama. Penerapan prinsip kerja sama dalam pembicaraan adalah wujud korelasi yang dilaksanakan demi terciptanya korespondensi yang efektif. Berdasarkan Merri Silvia Basri, Dkk (2021:242) menyebutkan bahwa aktivitas berbicara bisa dilakukan antara dua orang maupun lebih. Dalam penerapan prinsip kerja sama perlu terdapatnya kerja sama dalam tuturan yang bersifat responsif antara penutur dan lawan tutur. Satu komunikasi bisa dikatakan berhasil apabila penutur dan mitra tutur menerapkan prinsip maksim kerja sama dalam pertuturannya. Pengingkaran pada prinsip maksim kerja sama bisa diatasi oleh ilmu pragmatik yang mengkaji mengenai maksud penutur secara tersurat ataupun tersirat yang berada di balik tuturan yang dianalisis.

Dalam prinsip kerja sama maksim yang digagas Grice perlu diterapkan dalam peristiwa tutur. Teori mengatakan bahwa prinsip kerja sama itu menghendaki partisipan dalam bertutur harus sesuai dengan apa yang diminta, tuturan yang benar dan dapat dibuktikan kebenarannya, relevansi yang sesuai dengan apa yang dibicarakan, serta pada saat berbicara harus singkat, ringkas dan mudah untuk dipahami. Akan tetapi, pada hakikatnya dalam percakapan masih banyak peserta tutur yang mengabaikan empat maksim dalam prinsip kerja sama Grice.

Bagi masyarakat berbahasa Indonesia yang menjunjung tinggi nilai-nilai ketimuran seperti keramahan, akan terasa blak-blakan untuk menerapkan prinsip-prinsip kerja sama yang disarankan oleh Grice. Jika prinsip ini dipaksakan untuk diterapkan dalam konteks budaya Indonesia, maka akan berdampak pada kesantunan pertukaran yang berlangsung. Harus dipahami bahwa melanggar pedoman Grice untuk prinsip kerja sama tidak selalu menyebabkan kegagalan dalam komunikasi. Pelanggaran yang terjadi memang sengaja dilakukan dengan alasan yang berkaitan dengan kesantunan.

Pelanggaran terhadap maksim prinsip kerja sama terjadi bukan tanpa maksud. Terdapat latar belakang tersendiri yang melatarbelakangi seseorang melanggar maksim prinsip kerja sama. Contohnya, untuk mencairkan keadaan pembicaraan yang kaku seseorang bakal menyampaikan satu humor supaya keadaan pembicaraan berganti menjadi lebih informal. Namun, pada dasarnya perihal itu sudah menentang maksim prinsip kerja sama Grice. 
Menurut Fatmawati (2020:125-138), pelanggaran pada maksim prinsip kerja sama Grice terjadi disebabkan oleh beberapa alasan di antaranya, yakni: Pelanggaran pada maksim kuantitas terjadi karena ingin berbagi informasi, kesantunan, dan keramahan. Pelanggaran terhadap maksim kualitas disebabkan oleh keinginan menciptakan humor, berbohong, dan sindiran. Pelanggaran terhadap maksim relevansi terjadi karena menghindari tuturan langsung, penolakan, bercanda, dan penegasan. Selanjutnya, pelanggaran terhadap maksim cara/pelaksanaan terjadi karena bingung memberikan jawaban, lupa, gugup, empati, basa-basi, dan rahasia.

Suryani (2015:3), mengatakan bahwa maksim yang digagas oleh Grice tidak selalu dipatuhi oleh partisipan, pada situasi tertentu maksim-maksim prinsip kerja sama dilanggar untuk tujuan tertentu. Pernyataan tersebut didukung oleh pendapat Jazeri (2008:151), menyatakan bahwa pelanggaran maksim sering tidak bisa dihindari. Pelanggaran itu terjadi karena unsur kesengajaan dan unsur ketidaksengajaan. Pelanggaran yang terjadi karena unsur kesengajaan lebih menekankan pada permainan dan ejekan, dengan maksud supaya tuturannya memiliki efek tertentu, misalnya efek humoris dan santun dalam berbicara. Pelanggaran prinsip kerja sama karena ketidaksengajaan disebabkan oleh kegagalan dalam menggunakan maksim percakapan yang mengakibatkan penutur kesulitan dalam menafsirkan isi tuturannya.

Berdasarkan paparan di atas, bahwasanya pelanggaran maksim prinsip kerja sama sering terjadi dalam kejadian tutur terutama di budaya rakyat Indonesia. Adanya perbedaan penerapan maksim prinsip kerja sama yang dikemukan Grice dengan yang terjadi di Indonesia menyebabkan pelanggaran prinsip kerja sama sering terjadi. Latar belakang budaya yang terkandung dalam bahasa akan sangat mempengaruhi bahasa yang digunakannya. Jadi, tidak selamanya dalam percakapan harus memenuhi maksimmaksim yang digagas oleh Grice ada kalanya karena tujuan atau pada situasi tertentu terjadi pelanggaran. Maka dari itu, penulis terbujuk untuk melakukan eksplorasi perihal bentuk pelanggaran dan alasan terjadinya pelanggaran prinsip kerja sama.

\section{Kerangka Teori}

Dalam mengkaji pragmatik, konteks merupakan hal yang harus diperhatikan. Tanpa konteks, analisis pragmatik tidak dapat berlangsung. Konteks begitu penting dalam ilmu pragmatik Wijana (1996:2), yang menyatakan bahwa pragmatik mempelajari tafsir yang terkait oleh konteks. Menurut Nadar (2013:6), mengatakan bahwa konteks merupakan hal yang bergantung dengan ilmu sosial suatu paparan maupun dasar pemahaman yang sama-sama dimiliki oleh penutur dan mitra tutur yang dapat menunjang mitra tutur menjelaskan maksud perkataan. Selanjutnya, Fatmawati dkk (2020:1) menyebutkan bahwa konteks percakapan akan berpengaruh terhadap wacana yang dituturkan.

Terkait dengan konteks Nadar (2013:7-8), menjelaskan 8 (delapan) komponen yang memastikan konteks percakapan berlandaskan pandangan yang dikemukakan oleh Hymes. 8 (delapan) komponen itu disingkat dengan SPEAKING yaitu, setting, participants, ends, act of sequence, keys, instrumentalities, norms, dan genres. Setting adalah waktu dan tempat pembicaraan berlangsung, participants adalah orang yang terlibat dalam percakapan (peserta tutur), ends merupakan jangka yang hendak dipenuhi dalam percakapan, act of sequence adalah bentuk prosedur kata yang berupa ujaran ataupun tertulis, keys terkait dengan kaidah dalam lafal yang dilakukan, instrumentalities terkait dengan aturan berbicara dalam percakapan, norms norma dalam berhubung, dan genres merupakan jenis wacana. Delapan komponen di atas dapat melatarbelakangi munculnya 
suatu percakapan. Supaya prosedur korespondensi antara penutur dan mitra tutur bisa berlangsung dengan baik, setiap partisipan harus bisa saling bekerja sama.

Grice dalam Rahardi (2005:52), juga mengemukakan bahwa supaya amanat bisa sampai dengan benar pada peserta tutur, maka harus mempertimbangkan maksim prinsip-prinsip kerja sama. Untuk kelancaran suatu komunikasi partisipan harus menaati maksim prinsip kerja sama. Menurut Grice prinsip kerja sama tertuang dalam 4 maksim yang wajib ditaati oleh partisipan tutur, empat maksim percakapan tersebut di antaranya. Pertama, maksim kuantitas. Kedua, maksim kualitas. Ketiga, maksim relevansi, dan keempat adalah maksim cara/pelaksanaan. Namun, pada kenyataannya dalam percakapan masih banyak partisipan tutur yang melanggar maksim dalam prinsip kerja sama. Berikut dijelaskan satu persatu.

Pertama, pelanggaran maksim kuantitas. Yule (2006:64), mengatakan dalam bertutur ada dua hal yang harus dilakukan. Pertama, melakukan percakapan informasi sesuai kebutuhan. Kedua, jangan biarkan percakapan lebih dari yang dibutuhkan. Dalam kriteria kuantitas, setiap peserta diharapkan memberikan informasi sebanyak atau sedikit mungkin, tergantung pada kebutuhan mitra bicara. Tuturan yang mengandung informasi yang sangat di butuhkan mitra tutur dapat dinyatakan sesuai dengan maksim kuantitas prinsip kerja sama Grice. Sebalikya, jika tuturan tersebut mengandung terlalu banyak informasi, maka dapat dikatakan bahwa maksim kuantitas dilanggar.

Kedua, pelanggaran maksim kualitas. Menurut Wijana (1996:48), mengatakan bahwa maksim kualitas mengharuskan tiap partisipan pembicara harus menyebutkan hal yang sesuai dengan faktanya, partisipasi partisipan percakapan seharusnya berlandaskan dengan bukti yang sesuai. Dalam maksim kualitas diminta bisa menyampaikan kontribusi informasi yang benar. Dengan kata lain baik penutur ataupun lawan tutur tidak menyampaikan apa yang dipikir salah dan tiap sumbangan percakapan seharusnya disertai dengan bukti yang sesuai. Jika, dalam suatu percakapan baik penutur maupun mitra tutur tidak mempunyai bukti yang memadai. Maka, bisa dikatakan sudah melanggar maksim kualitas prinsip kerja sama Grice.

Ketiga, pelanggaran maksim relevansi. Maksim relevansi adalah sebentuk batas dalam memberikan informasi. Dalam batas ini penutur maupun lawan tutur diwajibkan untuk bekerja sama dalam memberikan informasi supaya terbentuknya pembicaraan yang relevan dengan topik yang sedang diperbincangkan. Menurut Wijana (1996:49), menyebutkan bahwa maksim relevansi menghendaki partisipan pembicara menyumbangkan informasi yang sesuai dengan topik yang dibicarakan. Supaya terjadi kerja sama yang benar antara penutur dan lawan tutur, sehrusnya peserta tutur bisa menyampaikan sumbangan yang relevan atas suatu yang dipertuturkannya. Bertutur tetapi tidak menyampaikan sumbangan yang sesuai dengan yang dituturkan bisa dibilang melanggar maksim relevansi.

Keempat, pelanggaran maksim cara/pelaksanaan. Maksim cara/pelaksanaan adalah suatu batasan dalam pembicaraan yang menekankan supaya peserta tutur memberikan informasi dengan sederhana, tidak bermakna ganda, dan tidak berbelit-belit. Grice dalam Wijana (1996:50), menyatakan dalam maksim pelaksanaan partisipan tutur diharuskan bercakap secara langsung, tidak berbelit, dan tidak berlebih-lebihan juga selaras. Kunci maksim cara/pelaksanaan merupakan usahakan apa yang dituturkan gampang untuk dipahami, yang dipentingkan dalam maksim ini merupakan bagaimana taktik kita mengutarakan ide, pendapat, dan arahan pada orang lain. Apabila tuturan yang diberikan tidak jelas dan sulit untuk dipahami dapat dikatakan melanggar maksim cara/pelaksanaan. 
Kemudian, Dalam percakapan tidak selalu tuturan yang diucapkan harus menepati maksim prinsip kerja sama yang digagas oleh Grice, adakalanya karena tujuan atau pada situasi tertentu terjadi pelanggaran. Pelanggaran yang terjadi disebabkan oleh beberapa permasalahan sosial. Menurut Suryani (2015:5), mengatakan bahwa maksim yang digagas oleh Grice tidak selalu dipatuhi oleh partisipan, pada situasi tertentu maksimmaksim prinsip kerja sama dilanggar untuk tujuan tertentu. Jazeri (2008:151), mengatakan bahwa dalam sebentuk percakapan pelanggaran maksim acap tidak terhindari. Pelanggaran itu terjadi karena unsur kesengajaan dan unsur ketidaksengajaan.

Terkait dengan alasan pelanggaran maksim prinsip kerja sama, Rochmawati (2017:156), mengatakan bahwa humor atau lelucon akan mengakibatkan terjadinya pelanggaran terhadap maksim prinsip kerja sama Grice, yaitu pelanggaran maksim kuantitas, maksim kualitas, maksim relevansi, dan maksim cara/pelaksanaan. Kemudian, Lili (2012: 94) dalam artikelnya mengatakan kalau alibi pelanggaran maksim-maksim prinsip kerja sama bisa disebabkan karena seseorang memberikan penjelasan tambahan dan tidak berencana menciptakan konflik dalam hubungan kemasyarakatan. Chaer (2010) mengatakan bahwa pelanggaran pada maksim prinsip kerja sama disebabkan oleh sejumlah hal, yaitu. Adanya kemauan partisipan untuk menyampaikan sumbangan berlebihan saat berbicara, respons atas tanggapan lawan tutur, kemauan akan menciptakan situasi menjadi santai, dan adanya usaha akan menciptakan penjelasan yang diberikan menjadi kabur.

Lebih detail Fatmawati (2020:154-156) membagi alasan pelanggaran maksim prinsip kerja sama Grice sebagai berikut. Pertama pelanggaran pada maksim kuantitas terjadi karena beberapa alasan, di antaranya: berbagi informasi, keramahan, kesantunan, dan keakraban. Kedua, alasan pelanggaran maksim kualitas terjadi karena humor dan berbohong. Ketiga, alasan pelanggaran maksim relevansi yang paling sering terjadi karena penolakan. Selanjutnya, alasan pelanggaran maksim cara/pelaksanaan berkaitan dengan kesantunan, dan tuturan disampaikan secara tidak langsung.

Berdasarkan beberapa hasil penelitian terdahulu, disimpulkan bahwa pelanggaran terhadap maksim prinsip kerja sama Grice benar-benar terjadi. Pelanggaran tersebut dikarenakan sejumlah alasan. Adapun alasan pelanggaran prinsip kerja sama Grice, yakni sebagai berikut: Pertama, pelanggaran terhadap maksim kuantitas bisa terjadi karena ingin berbagi informasi, keramahan, kesantunan, kejelasan, dan persuasi. Kedua, pelanggaran terhadap maksim kualitas bisa terjadi karena ingin bercanda, dan berbohong. Ketiga, pelanggaran terhadap makism relevansi biasa terjadi karena penolakan. Keempat, pelanggaran terhadap maksim cara/pelaksanaan terjadi karena ingin terlihat santun dan menyampaikan tuturan secara tidak langsung.

\section{Metode}

Pendekatan yang digunakan dalam penelitian ini adalah pendekatan kualitatif. Pendekatan kualitatif menjadi satu deskripsi kompleks, melalui cakap, laporan terinci dari pengetahuan informan dan membuat riset atas kedudukan yang alamiah. Dalam eksplorasi ini menggunakan metode analisis isi. Menurut Bungin (2017:187), metode analisis isi adalah satu metode yang sistematis dan objektif akan menelaah kandungan amanat dan mengarahkan pesan, maupun cara untuk mengamati dan menelaah integritas penutur dan mitra tutur. Adapun Sumber data dalam penelitian ini merupakan aktivitas berbahasa yang terjadi dalam program Mata Najwa pada hari Rabu 28 Agustus 2020. Data dalam eksplorasi ini adalah semua tuturan yang melanggar maksim prinsip kerja sama 
yang dituturkan oleh Najwa Shihab dan narasumbernya dalam Program Mata Najwa sesuai dengan teori Grice (1975) tentang prinsip kerja sama. Teori maksim prinsip kerja sama tersebut melingkupi maksim kuantitas. Maksim kualitas. Maksim relevansi, dan maksim cara/pelaksanaan.

Teknik pengumpulan data dilakukan dengan beberapa teknik di antaranya: Teknik dokumentasi. Teknik simak, dan teknik catat. Kemudian, teknik analisis data yang digunakan dalam eksplorasi ini dilakukan dengan beberapa tahap. Pertama, penulis memberi kode terhadap data. Pengkodean yang diberikan dalam bentuk angka. Kedua, penulis mengklasifikasi sekaligus menganalisis data. Klasifikasi tersebut dilakukan untuk mengelaborasi bentuk pelanggaran maksim prinsip kerja sama yang terjadi dalam program Mata Najwa. Ketiga, penulis melakukan interpretasi terhadap temuan penelitian. Interpretasi dilakukan untuk memberikan pemaknaan terhadap hasil penelitian. Dalam melakukan interpretasi, peneliti menghubungkan temuan penelitian ini sama hasil penelitian yang sudah dilaksanakan oleh peneliti sebelumnya. Keempat, penulis menyimpulkan hasil penelitian berdasarkan data-data yang diperoleh.

\section{Hasil}

Tuturan yang dianalisis adalah tuturan antara pemandu acara dengan narasumber dalam Talk Show Mata Najwa ditemukan beberapa tuturan yang melanggar maksim prinsip kerja sama dan alasan terjadinya pelanggaran. Pelanggaran pada maksim prinsip kerja sama dalam program Mata Najwa meliputi: (1) maksim kuantitas; (2) maksim kualitas; (3) maksim relevansi; (4) maksim cara/pelaksanaan. Temuan data tuturan bentuk pelanggaran dan alasan terjadinya pelanggaran dalam program Mata Najwa akan dipaparkan di bawah ini.

\section{Pelanggaran Maksim Kauntitas dan Alasan Pelanggarannya}

\section{Data 1}

Konteks: Tuturan ini terjadi di awal pembukaan acara pada sekmen satu. Partisipan dalam tuturan ini berjumlah dua orang, yakni Najwa Sihab sebagai pemandu acara dan Hary Setiyono seorang (Menteri Koordinator Politik Hukum dan Ham Jakarta Selatan) sebagai salah satu narasumber di acara Mata Najwa. Tujuan percakapan tersebut adalah untuk mengetahui kabar dari Hary Setiyono yang akan dimintai keterangan terkait terbakarnya gedung Kejaksaan Agung. Tuturan ini bermula saat pemandu acara (Najwa Sihab) mulai membuka diskusi dan menyapa semua narasumber salah satunya Hary Setiyono tersebut, sehingga terjadilah percakapan sebagai berikut.

NS: "Empat hari setelah kebakaran melanda markas jaksa, spekulasi masih terus bermunculan penyebab kebakaranpun masih jadi pengusutan kasus kebakaran ini, hadir di studio mata Najwa kepala pusat penerangan dan hukum kejaksaan agung Hary Setiono. Selamat malam Pak Hary".

HS : "Selamat malam, salam sehat untuk semuanya" (1)

PELANGGARAN: Tuturan (1) di atas termasuk pada pelanggaran prinsip kerja sama Grice. Pelanggaran tersebut dikategorikan kedalam pelanggaran maksim kuantitas. 
Pelanggaran tersebut tergambar dari jawaban Hary yang berlebihan. Hal tersebut bertentangan dengan prinsip kerja sama Grice. Grice menyatakan bahwa dalam maksim kuantitas tidak menghendaki lawan tutur memberikan penjelasan yang panjang ataupun singkat. Tuturan (1) terlihat bahwa Hary berlebihan dalam menjawab pertanyaan Najwa yang seharusnya Hary cukup menjawab "selamat malam". Namun pada percakapan di atas, Hary menambahkan ucapan "salam sehat untuk semuanya" yang menyebabkan terjadinya pelanggaran terhadap maksim kuantitas.

ALASAN PELANGGARAN: Alasan terjadinya pelanggaran maksim kuantitas pada data (1) karena Hary ingin terlihat lebih ramah dan santun. Hal tersebut tergambar pada tuturan Hary yang memberikan penambahan informasi yang tidak dibutuhkan oleh Najwa yaitu "salam sehat untuk semuanya" pada tuturan tersebut menunjukkan keramahan dan kesantunan karena memberikan doa kepada orang lain baik itu untuk Najwa, narasumber, maupun penontonnya yang tergambar pada kata "semuanya".

\section{Pelanggaran Maksim Kaulitas dan Alasan Pelanggarannya}

Konteks: Tuturan ini terjadi antara Muhammad Mahfud MD (Menteri Koordinator Politik Hukum dan Ham) dan Najwa Shihab sebagai pemandu acara. Dalam sekmen dua. Pada sekmen ini topik yang dibahas adalah tenteng persetujuan Mahfud MD untuk mengundang KPK dalam melakukan penyelidikan. Sebelumnya Bonyamin meminta untuk persetujuan Mahfud langsung diimplementasikan dan menghubungi Jaksa Agung, lalu di respons oleh Mahfud dan Najwa, seperti percakapan di bawah ini.

MM: "Itu, tu tinggal cara saya hahahhhahhaa"

NS : "Yang jelas, ini sudah terbuka dan disaksikan jutaan orang jadi seharusnya ini sudah"

PELANGGARAN: Data tuturan di atas tergolong pada pelanggaran maksim prinsip kerja sama Grice. Maksim yang dilanggar adalah maksim kualitas. Pelanggaran tersebut tergambar dari pernyataan NS menyebutkan yang tidak sebenarnya yaitu tuturan Disaksikan jutaan orang. Hal tersebut bertentangan sama maksim prinsip kerja sama Grice. Grice menyatakan bahwa dalam maksim kualitas menghendaki tiap partisipan percakapan menyampaikan apa yang sebenarnya. Berlandaskan pada bukti yang sesuai. Pernyataan yang diberikan NS merupakan pernyataan yang tidak sebenarnya, tidak adanya bukti yang menunjukkan bahwa yang menyaksikan acara tersebut mencapai jutaan orang sehingga menyebabkan pelanggaran maksim kualitas.

ALASAN PELANGGARAN: Alasan pelanggaran maksim kualitas tersebut karena NS memperkirakan bahwa yang menonton sebanyak itu dengan mengatakan hal yang tidak sebenarnya. Hal tersebut dilakukan oleh NS karena tidak memiliki jawaban yang pasti. Seharusnya NS mengatakan Ditonton oleh banyak orang tanpa menambahkan kata jutaan.

\section{Pelanggaran Maksim Relevansi dan Alasan Pelanggarannya}

Konteks: Tuturan ini terjadi antara Najwa Shihab sebagai pemandu acara dan Muhammad Mahfud MD (Menteri Koordinator Politik Hukum dan Ham) dalam 
sekmen dua. Sekmen ini Najwa kembali menghubungi Mahfud melalui video call. Lalu Najwa mengajukan pertanyaan kepada Mahfud tentang pernyataan Mahfud yang menyebutkan bahwa pemerintah tidak mungkin berbohong. Seperti percakapan di bawah ini.

NS: "Bara di markas Jaksa, saya akan kembali menghubungi menkopulhukam bapak Muhammad Mahfud MD, Pak Mahfud anda berkali-kali menyebutkan tidak mungkin pemerintah menyembunyikan sesuatu dalam situasi seperti ini, pertanyaannya Pak, pemerintah itu maksudnya presiden Jokowi, atau menkopulhukamnya Pak Mahfud MD atau aparat-aparat dibawahnya Pak?

MM: "Semua menurut saya kalau pemerintah main-main, kalau pemerintah berani berarti dia melanggar sebuah ketidak mungkinan dia lakukan, karena tidak ada yang disembunyikan sekarang ini, oleh sebab itu jangan berspekulasi karena kalau anda berbohong hari ini menyembunyikan sesuatu anda tidak akan bisa tidur mencari alasan baru untuk besok, oleh sebab itu kalau saya katakan saja bahwa tidak mungkin dan yang saya katakan yang saya yakini hari ini, karena seumpama saya apa, misalnya besok harus ketemu orang lagi ya saya tidak mencari kebohongan baru, jadi sekarang siapapun pejabat jangan coba berbohonglah, nanti akan ketahuan"

PELANGGARAN: Data tuturan di atas tergolong pada pelanggaran maksim prinsip kerja sama Grice. Maksim yang dilanggar adalah maksim relevansi. Pelanggaran tersebut tergambar dari respons MM yang kurang sesuai dengan pertanyaan yang dikemukakan NS. Perihal itu berlawanan dengan prinsip kerja sama Grice. Grice menyatakan bahwa dalam maksim relevansi menginginkan supaya partisipan menyampaikan sumbangan yang sinkron dengan topik pembahasan. Pada tuturan di atas MM memberikan jawaban melenceng dari pertanyaan NS, terlihat pada tuturan Semua menurut saya kalau pemerintah main-main, kalau pemerintah berani berarti dia melanggar sebuah ketidak mungkinan dia lakukan, karena tidak ada yang disembunyikan sekarang ini, oleh sebab itu jangan berspekulasi karena kalau anda berbohong hari ini. Respons MM tersebut tetap bisa dikatakan relevan dengan pertanyaan NS yaitu untuk menjelaskan siapa yang berbohong. Namun, tuturan MM di atas tidak ditemukan jawaban dari pertanyaan NS, sehingga menyebabkan terjadinya pelanggaran terhadap maksim relevansi.

ALASAN PELANGGARAN: Tuturan di atas termasuk pelanggaran maksim relevansi. Namun, alasan pelanggarannya berbeda dari apa yang sudah disampaikan teori. Teori menyebutkan bahwa alasan pelanggaran maksim relevansi adalah karena humor atau lelucon, dan penolakan. Namun ternyata, berdasarkan data tuturan tersebut ditemukan alasan pelanggaran maksim relevansi disebabkan karena MM membuat informasi yang disampaikan menjadi samar. Hal tersebut tegambar pada kalimat Semua menurut saya kalau pemerintah main-main, kalau pemerintah berani berarti dia melanggar sebuah ketidak mungkinan dia lakukan, karena tidak ada yang disembunyikan sekarang ini. Tuturan tersebut kurang jelas, yang dimaksud ketidak mungkinan itu apa. 


\section{Pelanggaran Maksim Cara/pelaksanaan dan Alasan Pelanggarannya}

Konteks: Tuturan ini terjadi antara Najwa Shihab sebagai pemandu acara dengan Muhammad Mahfud MD seorang (Menteri Koordinator Politik Hukum dan Ham Jakarta Selatan) mereka berbincang secara virtual dalam sekmen satu. Peristiwa tutur ini bermula saat Najwa bertanya tentang ketidak wajaran terbakarnya gedung Jaksa Agung. Kemudian, Najwa merespon jawaban dari Mahfud seperti percakapan di bawah ini.

MM: “Oo begini, saya katakan masyarakat jangan berspekulasi, itukan ada di TV ya, spekulasi apa Pak, spekulasi yang saya baca di medsos itu, itu nda masuk akal gitu, lalu media itu banyak yang menulis kata Mahfud MD terbakarnya nda masuk akal, padahal saya mengutip medsos, yang berkembang ketika itu masyarakat mengatakan di medsos itu, ini ndak masuk akal kok dari lantai enam turun ke-empat turun ke-lima, masa kalo listrik separah itu, itu kata masyarakat. Oleh sebab itu saya katakan jangan berspekulasi lah, spekulasi apa, ya itu yang ada di masyarakat bahwa kok turun dari lantai enam ke-empat ke-tiga.

NS: “Tapi dari pengamatan Pak maaf” (7)

PELANGGARAN: Data tuturan di atas dikatakan melanggar maksim prinsip kerja sama Grice. Maksim yang dilanggar adalah maksim cara/pelaksanaan. Dikatakan melanggar karena kadar kejelasannya rendah dan kadar kekaburannya sangat tinggi. Menurut Grice dalam maksim cara/pelaksanaan partisipan diminta berujar secara jelas, dan tidak berbelit-belit. Kalimat Tapi dari pengamatan Pak maaf tidak menyampaikan informasi atas apa yang sebetulnya diinginkan oleh lawan tutur. Jadi maksudnya pun menjadi amat samar. Disebut seperti itu karena kalimatnya bisa diartikan dengan beragam dan bisa membuat pengertian luas karena dalam cakap di atas tidak diberitahu apa semestinya yang diminta oleh NS. Pelanggaran tersebut terjadi karena ketidaklangsungannya dalam berbicara.

ALASAN PELANGGARAN: Alasan pelanggaran maksim pelaksanaan data tersebut karena NS merespons jawaban MM dengan santun. Hal tersebut tergambar pada kata Pak maaf. Fatmawati (2020:137) mengatakan bahwa salah satu alasan pelanggaran maksim cara/pelaksanaan adalah berkaitan dengan kesantunan.

Pada bagian ini, penulis menginterpretasi hasil pengolahan data mengenai pelanggaran dan alasan terjadinya pelanggaran maksim prinsip kerja sama Grice tuturan Najwa Shihab dan Bintang tamunya dalam program Mata Najwa. Fajrin dan Rohmadi (2016) yang menyatakan pelanggaran maksim prinsip kerja sama Grice berlaku pada seluruh maksim. Hal tersebut membuktikan prinsip kerja sama Grice tidak dapat digunakan secara global pada semua bahasa. Perihal itu tak luput dari adat dan budaya yang ada dalam setiap bahasa yang dipakai. Pernyataan tersebut diperkuat Murray (2009) dalam artikelnya menyebutkan bahwa upaya dari seorang untuk menaati ataupun menentang batasan maksim dan akibat yang diraih bakal beraneka ragam berlandaskan bahasa dan budaya yang digunakan.

Bagi masyarakat Indonesia, pelanggaran terhadap maksim prinsip kerja sama Grice bahkan untuk memperhatikan adab dalam berkomunikasi. Hubungan yang acap 
menggunakan prinsip kerja sama Grice. Bagi masyarakat tutur di Indonesia justru dianggap melalaikan adab dalam berinteraksi. Hal tersebut menandakan bahwa ditemukan selisih jenis prinsip kerja sama yang berlangsung pada budaya tutur di Indonesia. Hal tersebut diperkuat dengan pernyataan H. Tupan dan Natalia (2008) menyebutkan bahwa maksim prinsip kerja sama hubungan dalam beberapa situasi tidak ditaati secara terencana dengan alasan individu.

Budaya bahasa yang berbeda satu sama bahasa yang lainnya mengakibatkan perbedaan dalam menerepkan maksim prinsip kerja sama. Maka dari itu, maksim prinsip kerja sama Grice tidak dapat dipaksa semuanya untuk diterapkan pada bahasa tertentu. Apabila diterapkan maka akan terjadi pelanggaran. Terkait dengan alasan pelanggaran maksim prinsip kerja sama, Jazeri (2008:151) menyebutkan bahwa dalam sebuah percakapan, pelanggaran maksim sering tidak terelakkan, pelanggaran tersebut terjadi karena unsur kesengajaan dan unsur ketidak sengajaan. Pernyataan tersebut sehaluan dengan perolehan penelitian ini, pelanggaran pada maksim prinsip kerja sama Grice dikarenakan beberapa alasan baik itu alasan secara individu maupun alasan yang terkait sama budaya. Berlandaskan pembahasan di atas, berikut ini akan diuraikan secara detail pembahasan pelanggaran maksim prinsip kerja sama Grice dan alasan pelanggarannya.

\section{Simpulan}

Berlandaskan hasil temuan penelitian ini bisa disimpulkan bahwa pelanggaran yang terjadi pada maksim-maksim prinsip kerja sama Grice perkataan antara pemandu program dengan narasumber dalam program Mata Najwa adalah wujud dari budaya tutur bagi masyarakat di Indonesia. Prinsip kerja sama Grice tak dapat diterapkan secara mendunia. Pola maksim prinsip kerja sama Grice berselisih dengan budaya tutur rakyat Indonesia. Berdasarkan hasil penelitian, meskipun terjadi pelanggaran mitra tutur tidak mempermasalahkannya dan percakapan tetap berjalan dengan baik. Pelanggaran pada maksim prinsip kerja sama Grice adalah hal yang biasa terjadi. Perselisihan antara budaya mengakibatkan maksim prinsip kerja sama Grice tak dapat diterapkan secara global pada seluruh bahasa khususnya yang terjadi dalam program Mata Najwa. Pelanggaran pada prinsip kerja sama Grice bukanlah suatu kejelekan dalam berkomunikasi, pelanggaran tersebut bahkan dibutuhkan karena dampak budaya yang ada dalam suatu bahasa.

\section{Ucapan Terima Kasih}




\section{Daftar Pustaka}

Bungin, Burhan. 2017. Metode Penelitian Kualitatif. Depok: Rajawali Pers.

Chaer,Abdul. 2010. Kesantunan Berbahasa. Jakarta: Rineka Cipta.

Fajrin,R\&Muhammad Rohmadi. 2016. Pelanggaran Prinsip Kerja Sama dan Pematuhan Prinsip Kesantunan dalam Pembelajaran Bahasa Indonesia di SMK Pelayaran Akpelni Semarang. Jurnal S2 Pendidikan Bahasa Indonesia. 1(1), 100-112.

Fatmawati,dkk. (2020). The Realization Of Students' Polite Rejection Speeches. Indonesia: Universitas Negeri Jakarta.

Fatmawati. (2020). "Prinsip Kerja Sama dalam Peristiwa Tutur Masyarakat Riau Penelitian Grounded Theory di Program Studi Pendidikan Bahasa dan Sastra Indonesia FKIP Universitas Islam Riau". Disertasi. Jakarta: Ilmu Pendidikan Bahasa: Universitas Negeri Jakarta.

H.Tupan,A\&Natalia, H. 2008. The Multiple Violations of Conversational Maxims in Lying Done By the Characters in Some Episodes of Desperate Housewives. KaTa. 10(1), 6378. https://doi.org/10.9744/kata.10.1.63-78.

Jazeri. (2008). Realisasi Prinsip Kerjasama Dalam Sebuah Interaksi. Jurnal diksi. Vol 15. No2.STAIN.Tulungagung. https://journal.uny.ac.id/index.php/diksi/article/view/6603/5663. Diakses 18 Januari 2021.

Lili, Zhan. (2012). Understanding Humor Based on the Incongruity Theory and the Cooperative Principle Studies in Literature and Language, 7(8). file:///C:/Users/user/Downloads/2472-3199-3-PB.pdf. Diakses 15 Januari 2021.

Merri Silvia Basri, Dkk. 2021. Kesantunan Berbahasa: Studi pada Pembelajaran Daring. Vol 7. No 1. https://e-journal.my.id/onoma/article/view/625/1039. Diakses 11 Juni 2021.

Murray, N. (2009). Pragmatics, awareness raising, and the cooperative principle. ELT Journal. https://doi.org/10.1093/elt/ccp056.

Nadar,F.X. (2013). Pragmataik\&Penelitian Pragmatik. Yogyakarta: Graha Ilmu.

Rahardi,Kunjana. 2005. Pragmatik Kesantunan Imperatif Bahasa Indonesia. Jakarta: Penerbit Erlangga.

Rochmawati, Dyah. (2017). Pragmatic and Rhetorical Strategies in the Enghlish-Written Jokes. Indonesian Journal of Applied Linguistics. 7(1), 149-159. file://C:/Users/user/Downloads/6868-13756-1-PB.pdf. Diakses 15 Januari 2021.

Suryani, Intan. 2015. “Analisis Pelanggaran Prinsip Kerja Sama dalam Acara Talkshow Hitam Putih di Trans 7" Skripsi. Pekanbaru:Pendidikan Bahasa dan Sastra Indonesia, Universitas Islam Riau. 
Vol. 7, No. 2, 2021

ISSN 2443-3667 (print) 2715-4564 (online)

Wijana,I Dewa Putu.1996. Dasar-dasar Pragmatik. Yogyakarta: Andi Yogyakarta. Yule, George.2006. Pragmatik. Yogyakarta: 